\title{
Histopathological Changes Induced by Monosodium Glutamate and Sodium Nitrite in the Development of Eye in Albino Mice Mus musculus
}

\author{
Sanabel A. AIThanoon ${ }^{1 *}$, Ali Ashker Abd ${ }^{2}$ \\ ${ }^{1 *}$ Department of Biology, Education College for Pure Science, University of Mosul, Mosul, Iraq \\ ${ }^{2}$ Department of Anesthesiology, Al-Noor University College, Mosul, Iraq \\ E-mail: ${ }^{1 *}$ sanabel.althanoon@uomosul.edu.iq,$\underline{2 \text { ali.ashker@alnoor.edu.iq }}$
}

(Received April 05, 2021; Accepted June 22, 2021; Available online August 28, 2021)

DOI: 10.33899/edusj.2000.168650, (c) 2021, College of Education for Pure Science, University of Mosul.

This is an open access article under the CC BY 4.0 license (http://creativecommons.org/licenses/by/4.0/).

\begin{abstract}
The present study aimed to discover the histopathological of the Monosodium glutamate (MSG), and Sodium nitrite $\left(\mathrm{NaNO}_{2}\right)$, on the embryonic development of the eyes of albino mice Mus musculus. On the fourteenth and eighteenth day of pregnancy, the stage of organogenesis in these animals. A concentration of $9 \mathrm{~g} / \mathrm{kg}$ of MSG, a concentration of $110 \mathrm{mg} / \mathrm{kg}$ of $\mathrm{NaNO}_{2}$, and the interaction between them used. The results of the study showed the presence of pathological changes to the eyes of the fetuses. The eye on the 14th day of pregnancy, when $9 \mathrm{~g} / \mathrm{kg}$ of MSG used, there were retinal duplication, increased vascularization in the retina, condensation of some nuclei of the inner nuclear layer and ganglion cells, and necrosis in the vicinity of the lens. When treating with $\mathrm{NaNO}_{2} 110 \mathrm{mg} / \mathrm{kg}$, there was an irregularity in the lens, corneal distortion, hyperplasia of the retinal nerve tissue. When the two materials overlapped, the corneal tissue necrosis, the lens fiber, and the inner plexiform layer were observed. On the 18th day of pregnancy, when treated with MSG 9g/kg, the most significant overall and striking damage was retinal duplication and optic nerve necrosis. When treated with $\mathrm{NaNO}_{2} 110 \mathrm{mg} / \mathrm{kg}$, the corneal stroma and dissociation were seen in the photoreceptor cells. In the case of their overlapping, extensive necrosis and reduction appeared in all layers of the retina. The study concluded that consuming MSG and $\mathrm{NaNO}_{2}$ more than the permissible limit during pregnancy leads to tissue lesions harmful to the eye.
\end{abstract}

Keyword: food additives, fetal development of the eye, $\mathrm{MSG}, \mathrm{NaNO}_{2}$.

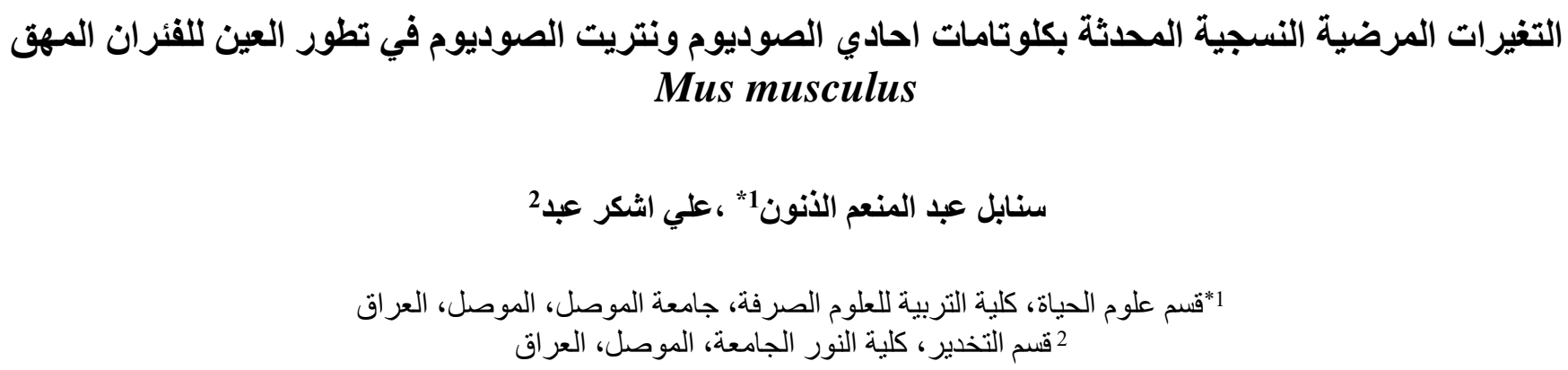




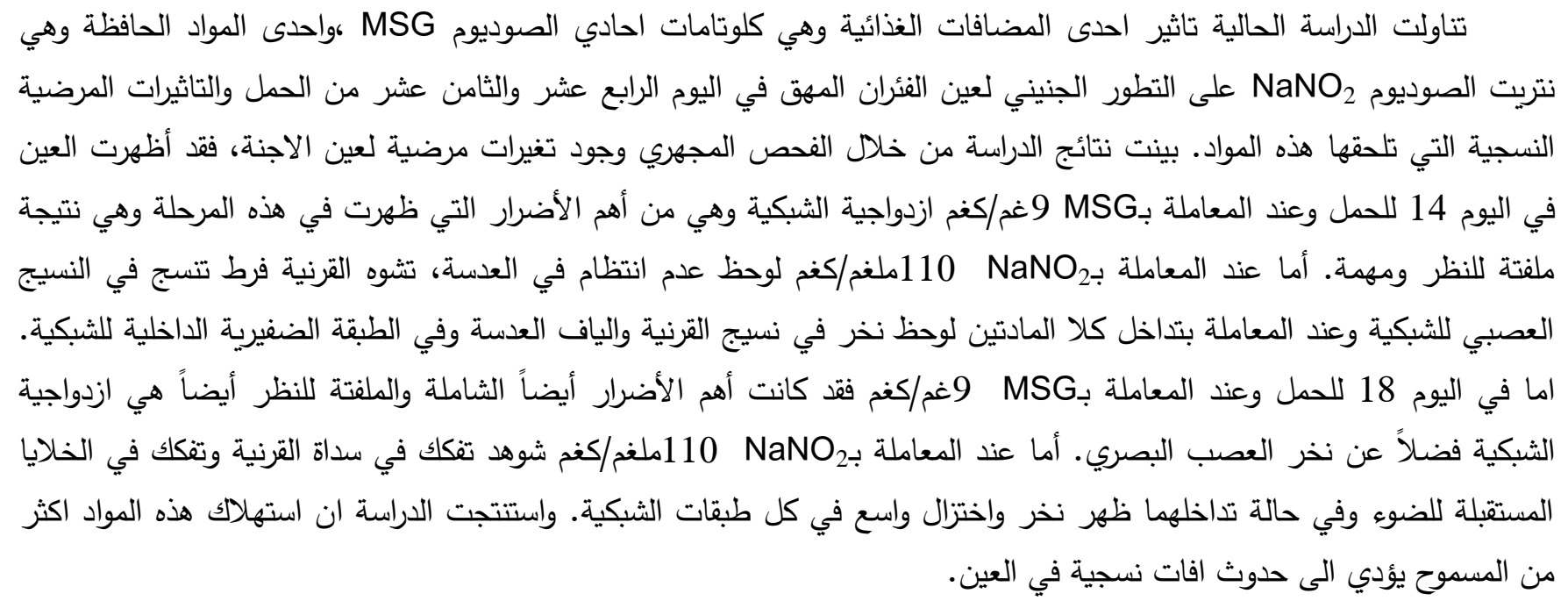

\section{Introduction}

Food additives can be defined as industrial or natural compounds added to food and are widely used in the food industries to increase the shelf life of the product and improve certain qualities in food, including coloring, preservation, and sweetening. Still, nevertheless, they have negative aspects, and some of them have been prohibited for their toxicity [1].

One of these substances widely used in the world is Monosodium glutamate (MSG), a substance that improves food flavor. It is a white crystalline powder [2]. It is the sodium salt of the non-essential amino acid Glutamic acid [3], symbolized as E621. It is used in the preparation of dried foods, canned soups, as well as in preserving frozen vegetables and fruits. It increases appetite and consumes large amounts of food, leading to obesity [4]. Also, glutamate and glutamate receptors contribute to an important role in many neurological diseases and pathological conditions of the eye, such as Ischemia and Trauma and Diabetic retinopathy, and Glaucoma [5].

The name of MSG is covered in foods under various names, including Umami or Ajinomoto. The US Food and Drug Administration considered it a safe and usable compound. The European Union classified it as a food additive that can be used in some foods, but according to specific conditions [6]. However, many studies recorded an increase in liver weight in rats given a diet containing MSG, which led to an increase in the activity of inflammatory tissue factors and led to hepatitis [7].

Sodium nitrite $\left(\mathrm{NaNO}_{2}\right)$ is also a food additive. It is a yellowish-white crystalline powder with unique pharmacological and industrial properties. It has been used in human and veterinary medicines as a vasodilator, antimicrobial agent, protection against hypoxia, and Preservative against bacterial contamination. [8]. $\mathrm{NaNO}_{2}$ added to food as a preservative may interact in the stomach with amino compounds in food and form nitrosamine compounds that can cause cancer [9]. It may also contribute to the emergence of compounds and free radicals that accelerate fat oxidation, which causes dangerous 
effects to various tissues and organs of the body. Therefore, $\mathrm{NaNO}_{2}$ is a toxic chemical, and it is harmful when exposed to it, as it irritates the eyes, skin, and lungs [10].

The vertebrate eye is one of the most important and sensory organs in the body, so it has a complex structure and function, as it receives incoming light and turns it into images through which we can see the world around us [11]. The mammals' eyes are similar in structure to the rest of vertebrate eyes, as they consist of three main layers. The external is the sclera which contains the cornea. The middle layer is the Uvea, and the inner is the retina, which is the most important layer, and it is the eye photoreceptor layer because it contains photoreceptors. There are differences in vertebrates' eyes in terms of numbers and types of cells and their organization and arrangement [12].

The eyes are sensitive to teratogenic effects and infectious factors, as visual defects may result from an infection of tissues and organs with some microorganisms during the fetal period, such as rubella virus and syphilis, as well as the physical and chemical factors that a pregnant mother may be exposed to, which may lead to a defect in Eye formation and some defects that may affect the visual process after birth. Most ophthalmic defects result from damaged closure of retinal fissures such as coloboma of the iris, cataracts, and glaucoma may result from intrauterine infections [13].

As a result of the previous, and to investigate the effect of MSG and $\mathrm{NaNO}_{2}$ on developing all parts of the eye in mice, this study was conducted.

\section{Materials and Methods}

- Laboratory animals

This study was conducted on Swiss white mice Mus musculus, and they were selected at an age ranging from (8-12) weeks, their average weight ranged $(2 \pm 23) \mathrm{g}$. They were placed in special laboratory conditions in terms of ventilation, temperature $(2 \pm 24)^{\circ} \mathrm{C}$ and photoperiod (12 hours of light / 12 hours of darkness) [14]. The mice were fed continuously with their food [15].

- Choosing of doses Concentration used in the study

The dose concentrations were selected in light of the median lethal dose 50 (LD $\left.\mathrm{L}_{50}\right)$ for MSG ranging from 15-18 g/kg B.W. [16] and for $\mathrm{NaNO}_{2}$ ranging from $85-150 \mathrm{mg} / \mathrm{kg} \mathrm{B.W.} \mathrm{[17].} \mathrm{The} \mathrm{doses} \mathrm{that} \mathrm{were}$ used in this study were as following: (9 g / kg) MSG, the dose was administered in $0.5 \mathrm{ml} \mathrm{D.W}$. orally by the Gavage needle, and $(110 \mathrm{mg} / \mathrm{kg})$ for $\mathrm{NaNO}_{2}$ in $0.1 \mathrm{ml} \mathrm{D.W}$. was given as intraperitoneal (I.P.) injection.

- Experimental Design

(24) pregnant mice were used, which were divided into four subgroups, as follows:

\begin{tabular}{|c|c|c|c|c|}
\hline Duration of treatment & Groups & $\begin{array}{c}\text { Material and } \\
\text { concentration }\end{array}$ & $\begin{array}{c}\text { Number of } \\
\text { treatment days }\end{array}$ & Number of mice \\
\hline \multirow{3}{*}{$\begin{array}{c}\text { From the seventh to } \\
\text { the eighteenth day of } \\
\text { pregnancy }\end{array}$} & Control & distilled water & 12 & 6 \\
\cline { 2 - 5 } & Group 1 & MSG 9g $/ \mathrm{kg}$ & 12 & 6 \\
\cline { 2 - 5 } & Group 2 & $\mathrm{NaNO}_{2} 110 \mathrm{mg} / \mathrm{kg}$ & 12 & 6 \\
\hline
\end{tabular}

- Histological sections preparation

The histopathological sections were attended by anesthetizing and dissecting the pregnant mice on the 14 th day and the 18th day of pregnancy for the control group and experimental groups mediated by 
Journal of Education and Science (ISSN 1812-125X), Vol: 30, No: 3, 2021 (1-12)

Special Issue for Proceeding of $3^{\text {rd }}$ National (1 ${ }^{\text {st }}$ international conference of biology) (ICBSUM 2021) 5, 6 July

College of Education for Pure Science, University of Mosul, Mosul, Iraq.

Chloroform. The embryos were extracted from the uterine horns [18] after gently removing the fetal membranes [19] .

The eyes extracted from its orbit and the tissue sections were prepared by passing a series of steps, based on Suvarna et al. [20] as the following: Fixation was done by neutral formalin for 24-48 hours, after which it washed with water for 20 minutes. Then they went through an ascending series of ethyl alcohol at concentrations of $30,50,70,90$, and $100 \%$ for $15 \mathrm{~min} . /$ con. except for the last one for an hour for dehydration. They were clearing with xylene for 30 minutes. infiltration and embedding were done using paraffin wax, its melting point $\left(54-56^{\circ} \mathrm{C}\right)$. Trimming and cutting were with a rotary microtome in a thickness of $5 \mu \mathrm{m}$. The histological sections were colored with Delafield's Haematoxylin and Eosin stain (H\&E) based on Al-Hajj 's method [21]. The sections loaded with D.P.X. Finally, they were examination and imaging was done with a digital camera attached to a compound optical microscope.

\section{Results}

\section{- Histopathological changes in the eye of fetuses aged $14^{\text {th }}$ days}

Microscopic examination of the histological sections of the fetuses' eyes at the age of $14^{\text {th }}$ days showed the emergence of pathological changes compared to the control group (Figure 1,2). When pregnant were treated with MSG, increased vascularization was observed in the retina, condensation of some nuclei of the inner nuclear layer and ganglion cells, and necrosis in the vicinity of the lens (Figure $3)$. One of the most important damages that appeared at this stage is a duplication of the retina. Also, necrosis appeared in the area of the photoreceptor cells and the lens (Figure 4).

When pregnant mice were treated with $\mathrm{NaNO}_{2}$, there was an irregularity of the lens, deformation of the cornea, thinning of the central part of it, hyperplasia of the retinal nerve tissue, and necrosis of the inner plexiform layer (Figure 5). This tissue damage may lead to a defect in the eye's fetal development process, which may ultimately cause a defect in the visual process after birth. 


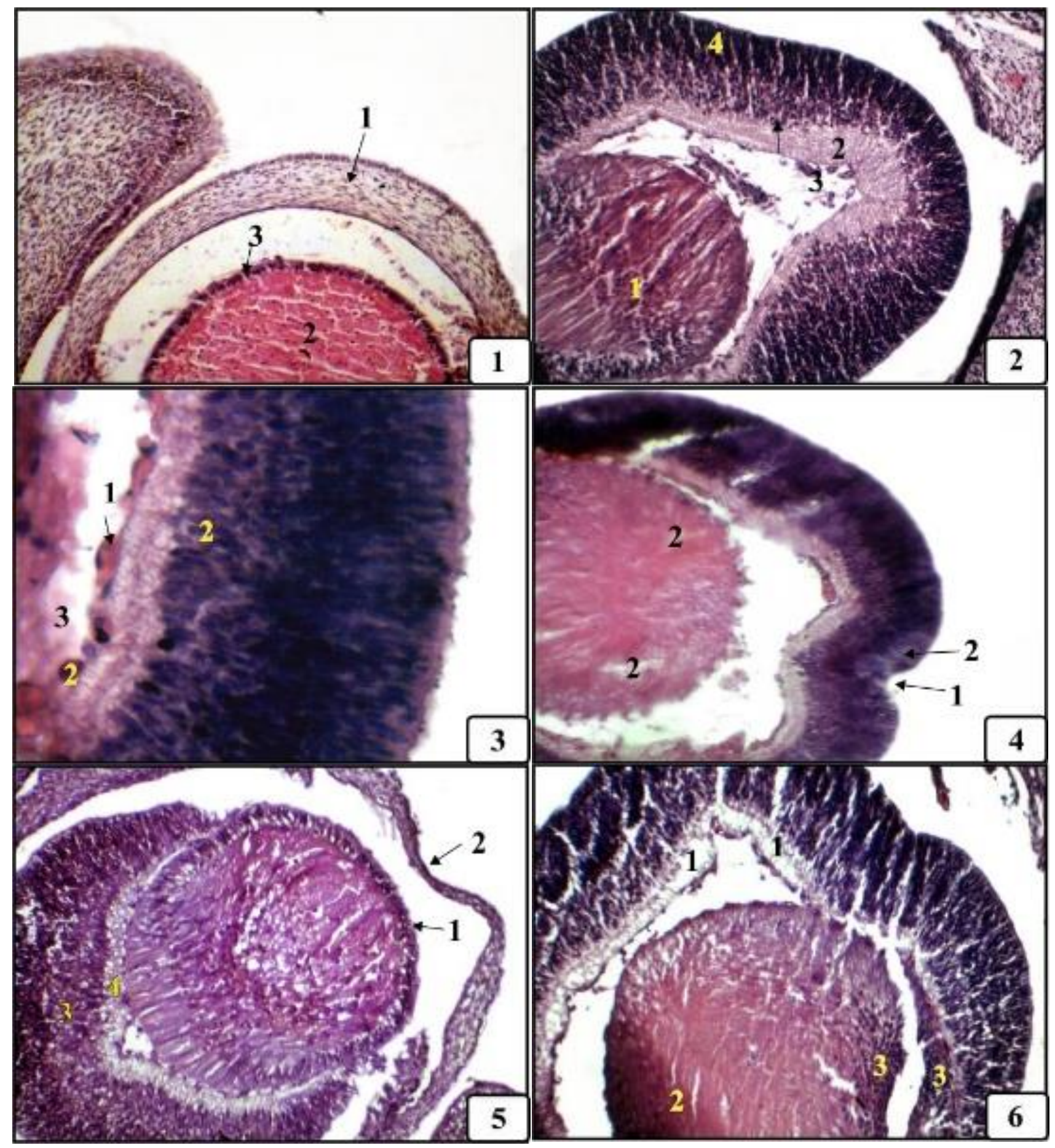

Figure (1): Histological section in the mouse's embryo eye (14 ${ }^{\text {th }}$ day of pregnancy) control group. 1: Cornea; 2 : lens fibers; 3: lens capsule. 100X.; Figure (2): Histological section in the mouse's embryo eye (14 ${ }^{\text {th }}$ day of pregnancy) control group. 1: lens; 2: inner plexiform layer; 3: ganglion cells layer; 4: rest of retina layers.; 40X. Figure (3): Histological section in the mouse's embryo eye $\left(14^{\text {th }}\right.$ day of pregnancy) group 1. 1: vascularization; 2 : condensation of nuclei; 3 : necrosis. 400X.; Figure (4): Histological section in the mouse's embryo eye (14 ${ }^{\text {th }}$ day of pregnancy) group 1.1 : retinal duplication; 2: necrosis. 100X.; Figure (5): Histological section in the mouse's embryo eye (14 ${ }^{\text {th }}$ day of pregnancy) group 2. 1: irregularity in the lens; 2: deformation of the cornea;3: nerves tissue; 4: necrosis. 100X. Figure (6): Histological section in the mouse's embryo eye ( $14^{\text {th }}$ day of pregnancy) group 3. 1: necrosis; 2 : deformation of the lens; 3 : infiltration of inflammatory cells. 100X. 
Journal of Education and Science (ISSN 1812-125X), Vol: 30, No: 3, 2021 (1-12)

Special Issue for Proceeding of $3^{\text {rd }}$ National (1 ${ }^{\text {st }}$ international conference of biology) (ICBSUM 2021) 5, 6 July

College of Education for Pure Science, University of Mosul, Mosul, Iraq.

In the case of the two substances being treated together, necrosis of the inner plexiform layer of the retina was observed, deformation of the lens with condensation of part of it, infiltration of inflammatory cells in a part of it, and the lining of the retina (Figure 6). also observed necrosis of the inner plexiform layer of the retina and increased awareness of the corneal tissue (Figure 7).

- Histopathological changes in the eye of the fetuses aged of $18^{\text {th }}$ days

In the eye of $18^{\text {th }}$ day old fetuses, several histopathological lesions were observed compared to the control group (Figure 8,9). When treated with MSG, the most striking damage was retinal duplication. Also appeared necrosis of the optic nerve and condensation of part of it (Figure 10) and in another part, in addition to retinal duplication, necrosis of the inner plexiform layer, reduction of the nervous tissue of a part of the retina, condensation of the lens (Figure 11). There was also a deformation of the lens, thickening of the epithelial tissue and its capsule, thickening of the cornea's inner lining, necrosis of the cornea's stroma, and deformation in another area of the cornea (Figure 12).

When treated with $\mathrm{NaNO}_{2}$, the retina showed necrosis on the outer and inner nuclear layer, the inner plexiform layer, the dissolution of the photoreceptor cells, and the infiltration of inflammatory cells the edge of the inner plexiform layer (Figure 13). In another part of the eye, dissociation of the cornea's stroma fibers was observed, reducing the cornea's superficial epithelial layer, condensation of the periphery of the lens (the capsular), and hyperplasia of its epithelium (Figure 14).

When the treatment with both MSG and $\mathrm{NaNO}_{2}$, extensive necrosis and reductions were observed in all retina layers (Figure 15). In the cornea, dissociation and necrosis of the stroma, reduction of the surface epithelium, and endothelial condensation were observed. Condensation of the lens's epithelium, hyperplasia, and necrosis of the fibers appeared (Figure 16).

\section{Discussion}

- Histopathological changes in the eye of fetuses aged $14^{\text {th }}$ days

When pregnant were treated with MSG, many histopathological changes was observed, they included increased vascularization, condensation of some nuclei, necrosis in the vicinity of the lens, duplication of the retina, and necrosis in the photoreceptor cells and the lens. The duplication of the retina is one of the most important damages that appeared. It did not appear in previous studies and is considered a first-time result to the best of our knowledge. Some of these results are also consistent with the results that were performed on birds, as it was observed when treating chicken embryos during an incubation period with MSG causing them to have both morphological and retinal deformations, as the eyes were damaged, especially retinal tissues [22,23]

In a study on pregnant mice, they were treated with MSG, as they were dosed from day 17 of pregnancy at different concentrations $2,4,8 \mathrm{~g} / \mathrm{kg}$ of body weight and studied the newborn's embryonic development mice's cornea. The histopathological changes were observed during different periods, including the stroma fibers puncture, necrosis and reduction of the corneal epithelial layer, hyperplasia of the peripheral corneal epithelium, and part of it deformed, corrugation of the basement membrane of the central corneal epithelium, distortion of the fibers of the central corneal stroma, corrugation of the anterior surface of the cornea, reduction layering and irregularity, hyperplasia of fibroblasts, significant breakdown of stroma fibers, damage on the peripheral of the corneal epithelial tissue, hyperplasia of the central cornea, a reduction in the peripheral cornea of the generative cells for fibers, the separation of the endothelial epithelial tissue and the appearance of the condensed layer on the epithelial tissue [24].

When pregnant mice were treated with $\mathrm{NaNO}_{2}$, there was an irregularity of the lens, deformation of the cornea, hyperplasia of the retinal nerve tissue, and necrosis of the inner plexiform layer. This tissue damage may lead to a defect in the eye's fetal development process, which may ultimately cause a defect in the visual process after birth. 
Journal of Education and Science (ISSN 1812-125X), Vol: 30, No: 3, 2021 (1-12)

Special Issue for Proceeding of $3^{\text {rd }}$ National (1st international conference of biology) (ICBSUM 2021) 5, 6 July College of Education for Pure Science, University of Mosul, Mosul, Iraq.

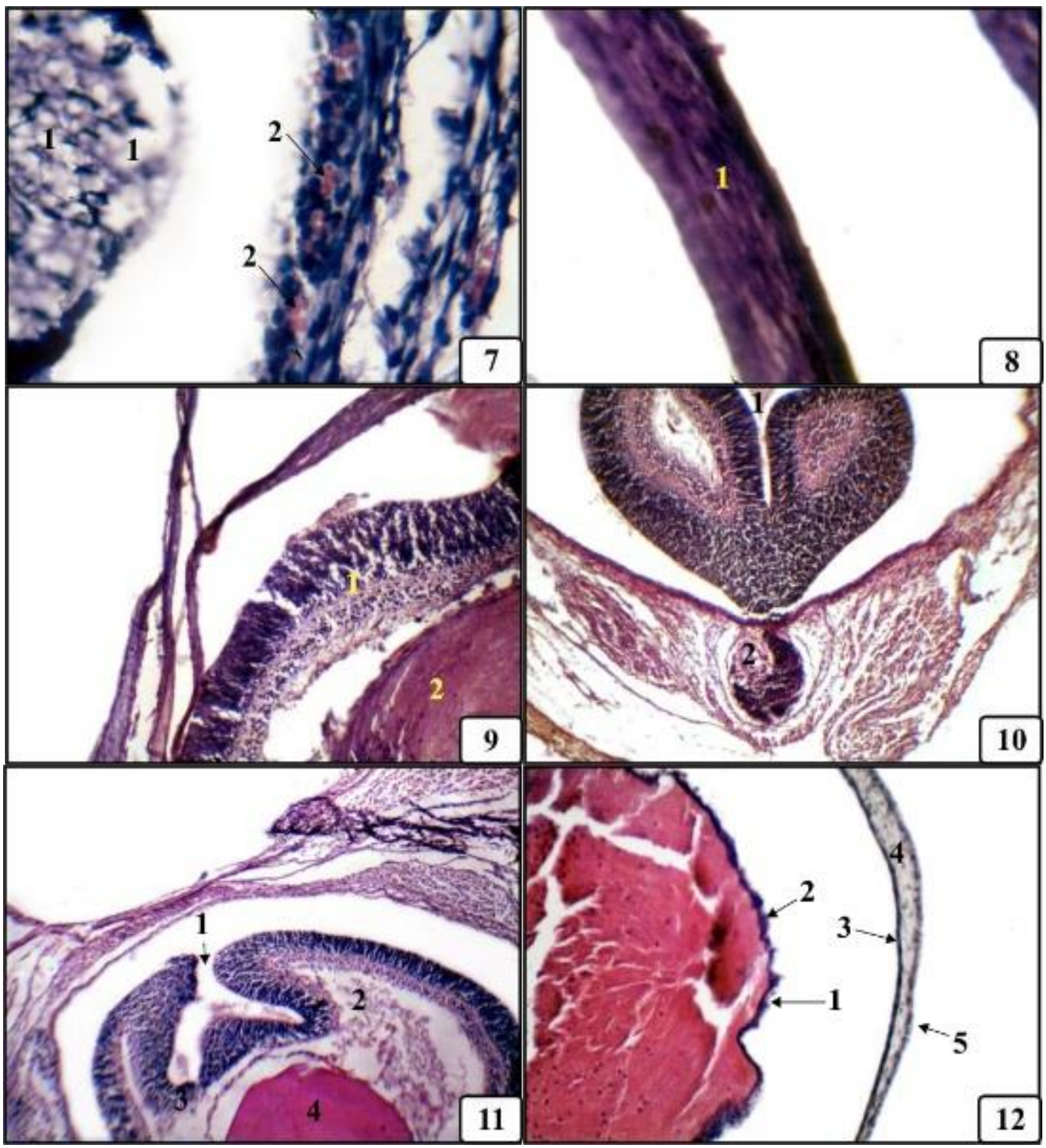

In the case of the two substances being treated together, necrosis of the inner plexiform layer of the

Figure (7): Histological section in the mouse's embryo eye (14 $4^{\text {th }}$ day of pregnancy) group 3. 1: necrosis; 2 : vascularization. 400X. ; Figure (8): Histological section in the mouse's embryo eye (18 ${ }^{\text {th }}$ day of pregnancy) control group. 1: cornea. 100X. Figure (9): Histological section in the mouse's embryo eye ( $18^{\text {th }}$ day of pregnancy) control group. 1: retina; 2: lens. 100X.; Figure (10): Histological section in the mouse's embryo eye (18 ${ }^{\text {th }}$ day of pregnancy) group 1. 1: retinal duplication; 2: necrosis. 40X.; Figure (11): Histological section in the mouse's embryo eye ( $18^{\text {th }}$ day of pregnancy) group 1. 1: retinal duplication; 2: necrosis; 3: reduction in neural tissue; 4: condensation in the lens. 40X. Figure (12): Histological section in the mouse's embryo eye (14 ${ }^{\text {th }}$ day of pregnancy) group1. 1: deformation of the lens; 2 : condensation in the lens; 3: condensation in the cornea; 4: deformation. 100X. 


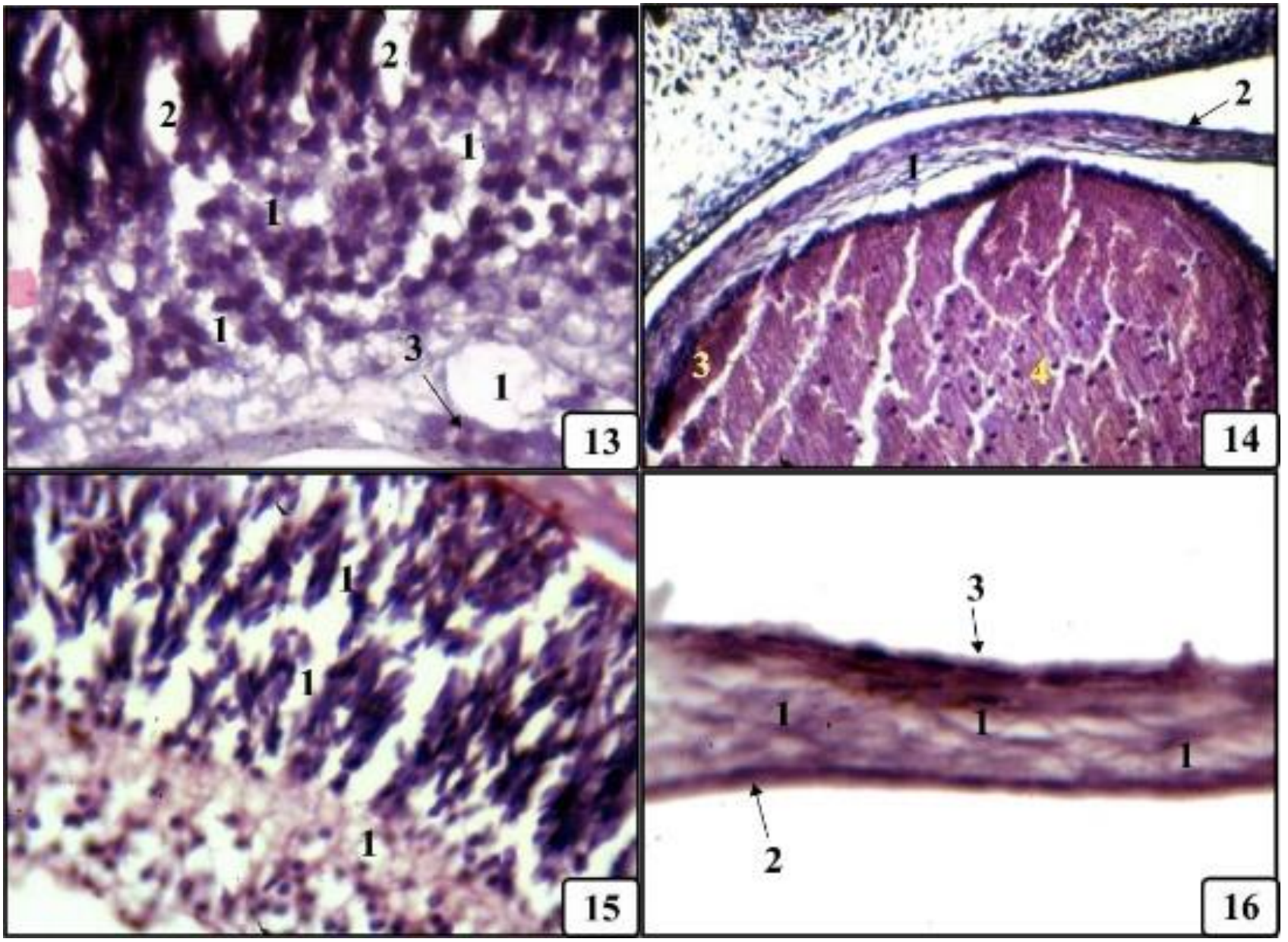

Figure (13): Histological section in the mouse's em bryo eye (18 th day of pregnancy) group 2. 1: necrosis; 2: dissociation in the photoreceptor cells;3: infiltration of inflam matory cells. 400X. Figure (14): Histological section in the mouse's embryo eye (18 $8^{\text {th }}$ day of pregnancy) group 2. 1: dissociation in cornea fibers;2: reduction in superficial epithelia; 3 : condensation in the lens; 4: hyperplasia in lens epithelial. 100X. Figure (15): Histological section in the mouse's embryo eye (18 $8^{\text {th }}$ day of pregnancy) group 3. 1: necrosis; 2: large reduction 400X.; Figure (16): Histological section in the mouse's embryo eye (18 ${ }^{\text {th }}$ day of pregnancy) group 3.1: dissociation and necrosis; 2 : rechuction in superficial eprithelia; $:$ condensation in the endothelium. 100X.

retina, deformation of the lens, infiltration of inflammatory cells, and necrosis of the inner plexiform layer were observed. These results confirm what was stated in the study of [25], as they demonstrated the presence of damage to the tissues of the eye as a result of ingesting these substances, which led to the emergence of widespread damage to the eye and gave a recommendation for the need for treatment. 
Journal of Education and Science (ISSN 1812-125X), Vol: 30, No: 3, 2021 (1-12)

Special Issue for Proceeding of $3^{\text {rd }}$ National (1 ${ }^{\text {st }}$ international conference of biology) (ICBSUM 2021) 5, 6 July

College of Education for Pure Science, University of Mosul, Mosul, Iraq.

- Histopathological changes in the eye of the fetuses aged of $18^{\text {th }}$ days

In the eye of $18^{\text {th }}$ day old fetuses, several histopathological lesions were observed. When treated with MSG, the most striking damage was retinal duplication. Also appeared necrosis of the optic nerve, necrosis of the inner plexiform layer, reduction of the nervous tissue. There was also a deformation of the lens, thickening of the cornea's inner lining, and necrosis of the cornea's stroma.

When treated with $\mathrm{NaNO}_{2}$, the retina showed necrosis, the dissolution of the photoreceptor cells, the infiltration of inflammatory cells the edge of the inner plexiform layer, dissociation of the cornea's stroma, reducing the cornea's superficial epithelial layer, condensation of the periphery of the lens, and hyperplasia of its epithelium.

When the treatment with both MSG and $\mathrm{NaNO}_{2}$, extensive necrosis and reductions, dissociation and necrosis of the stroma, reduction of the surface epithelium, endothelial condensation, condensation of the lens's epithelium, hyperplasia, and necrosis of the fibers appeared.

This study's results are in agreement with what Ibrahim [19]indicated about the effect of MSG on eye development, as it showed the emergence of different histopathological lesions of the cornea, lens, and retina with its secondary layers. The results of the current study are also to the findings of Al-Najjar [26] regarding the effect of smoking on the embryogenesis of the eye on the eighteenth day of pregnancy, which was hyperplasia of the central retina, thickening of the sclera layer, lens distention, corneal thickening, necrosis of the inner plexiform layer and condensation of ganglion cells. We find other previous studies on the effect of MSG alone and $\mathrm{NaNO}_{2}$ alone but not their overlap, and we believe that most of our results were recorded for the first time to our knowledge.

\section{Conclusion}

It can be concluded from this study that taking MSG and $\mathrm{NaNO}_{2}$ above the permissible limit for pregnant women may lead to clear damage in most eye tissues during their fetal development and ultimately visual impairment, so we recommend avoiding their use, especially in concentrations close to the average lethal dose.

\section{Acknowledgements}

The authors are very grateful to the University of Mosul, represented by Professor Dr. Qusay Kamal Al-Din Al-Ahmadi, and the College of Education for Pure Sciences for their provided facilities, which helped to improve the quality of this work.

\section{References}

[1] BO. Linke, TC. Casagrande and LC. Cardoso ,"Food additives and their health effects: A review preservative sodium benzoate",IEEE Afric.Biotech.vol.17,no.10,pp. 306-310,2018, doi.org/10.5897/ajb2017.16321 .

[2] RZ. Hamza and AA. Diab ,"Testicular protective and antioxidant effects of Selenium nanoparticles on Monosodium glutamate induced testicular strcture alterations in male mice",IEEE Toxic. Rep.vol. 7,pp.,254-260, 2020doi.org/10.1016/j.toxrep.2020.01.012 
Journal of Education and Science (ISSN 1812-125X), Vol: 30, No: 3, 2021 (1-12)

Special Issue for Proceeding of $3^{\text {rd }}$ National (1st international conference of biology) (ICBSUM 2021) 5, 6 July

College of Education for Pure Science, University of Mosul, Mosul, Iraq.

[3] MA. Al-Mosaibih ,"Effects of Monosodium glutamate and acrylamide on the liver tissue of adult wistar rats",IEEE Li. Sci.vol.10,no.25,pp. 35-42,2013. http://www.lifesciencesite.com/lsj/life1002s/007_15869life1002s_35_42.pdf

[4] JA. Fernandez and T. Hernandez "Effect of monosodium glutamate given oraly on Appetite control (A new theory for the Obesity Epidemic)",IEEE An. R. Acad. Nac. Med.vol.122,no.2,pp. $341-55,2005$. https://www.scielo.br/j/acb/a/hqZ5XqmDzZkdbNZHqtrJmGx/?lang=en

[5] NB. Sudha, AB. Raju and A. Ashok ."Effect of Memantine and Hespiridine on Monosodium Glutamate Induced Excitotoxicity in Rats". Ind. IEEE Phar. Edu. \& Res.vol.50,no.2 pp. 5258,2016. http://www.ijper.org/sites/default/files/10.5530ijper.50.2.18.pdf

[6] N. Elyazji, I. Abdel-Aziz, O. Shahwa and A. Lubbad," Effects of Monosodium Glutamate on Some Biochemical and Hematological Parameters in Adult Rabbits and Potential Protective Effect of Soybean Oil"IEEE Biol. Chem. Res.vol.32,no.1,pp. 131-141,2015.

[7] CH. Park, SH. Choi, Y. Piao, SH. Kim, YJ. Lee, HS. Kim and YH. Suh,"Glutamate and aspartate impair memory retention and damage hypothalamic neurons in adult mice",IEEE Toxic. Let. Vol.115,no.2,pp. 117-125,2000. doi:10.1016/s0378-4274(00)00188-0

[8] SM. Al-Hiti, AH. Hussain and AF. Al-Zabaidy," Evaluation of Histo-Pathological Changes in the Mice Exposed to Sodium Nitrite for Long Term by Using Hematoxylin and Eosin Staining",IEEE Inter. Pharma. Scie. \& Rese .vol.9,no.2,pp. 483-489, 2018.

[9] W. Zheng and SY. Wang ,"Antioxidant activity and phenolic compounds in selected herbs"IEEE Agric. Food Chem. vol.49,no.11,pp. 5165-5170,2001, doi.org/10.1021/jf010697n

[10] MT. Gladwin, JH. Crawford and RP. Patel ,"The biochemistry of nitric oxide, nitrite, and hemoglobin: Role in blood flow regulation",IEEE Free. Radic .Biol. Med. vol.36,no.6,pp. 707-717,2004, doi.org/10.1016/j.freeradbiomed.2003.11.032 . 
Journal of Education and Science (ISSN 1812-125X), Vol: 30, No: 3, 2021 (1-12)

Special Issue for Proceeding of $3^{\text {rd }}$ National (1st international conference of biology) (ICBSUM 2021) 5, 6 July

College of Education for Pure Science, University of Mosul, Mosul, Iraq.

[11] K. Rogers ,"The Eye. The Physiology of Human Perception." $1^{\text {st }}$ Ed. Britannica Educational Pub;. 143pp. 2011.

[12] BL. Finlay and B. Clancy,"Chronology of Development of the Mouse Visual System. Chalupa and R. W. Williams", $1^{\text {st }}$ Ed. The MIT Press;.257-265 pp. 2008

[13] KL. Moore, TN. Persaud and MG. Torchia," The Developing Human: Clinically Oriented Embryology", 10 ${ }^{\text {th }}$ Ed. Saunders Elsevier;. 417-428 pp. 2013

[14] JH. Abdul-Fattah," The effect of hypervitaminosis A as a cause of external \& some histological congenital Malformations in the swiss Mouse embryo". [Ph.D. dissertation]. Iraq, University of Mosul, College of Science Mosul;.88p. 2004.

[15] KK. Terry , DB. Stedman , B. Bolon and F. Welsch," Effects of 2-methoxyethanol on mouse neurulation",IEEE Teratology ,vol.54,no.5,pp. 219-29,1996; doi.org/10.1002/(sici)10969926(199611)54:5<219::aid-tera2>3.0.co;2-v

[16] TK. Bera , SK. Kar, PK. Yadav, P. Mukherjee, S. Yadav and B. Joshi," Effects of monosodium glutamate on human health: A systematic review",IEEE World J. of Pharma. Sci. vol.5,no.4,pp. 139-144,2017.

[17] FA. Ansari , SN. Ali , AA. Khan and R. Mahmood ,"Acute oral dose of sodium nitrite induces redox imbalance, DNA damage, metabolic and histological changes in rat intestine",IEEE PLOS One.vol.12,no.4,pp. 1-22,2017, doi.org/10.1371/journal.pone.0175196.

[18] RG. Sultan ,Pathological changes and congenital anomalies resulting from the experimental administration of some analgesic and narcotic substances in mice and their fetuses. [Ph.D. dissertation]. Iraq, University of Mosul, College of Education. Iraq;.36p. 2017.

[19] MN. Ibrahim, Induced histopathological changes of monosodium glutamate on ocular growth and composition in Swiss white mice Mus musculus. [Ph.D. dissertation]. Iraq, University of Tikrit.Iraq;. 23-56p. 2017. 
Journal of Education and Science (ISSN 1812-125X), Vol: 30, No: 3, 2021 (1-12)

Special Issue for Proceeding of $3^{\text {rd }}$ National (1st international conference of biology) (ICBSUM 2021) 5, 6 July

College of Education for Pure Science, University of Mosul, Mosul, Iraq.

[20] SK. Suvarna, C. Layton and JD. Bancroft," Bancroft's theory and practice of histological "techinques. $8^{\text {th }}$. Elesvier;.234p. 2019.

[21] HA. Al-Hajj ,"Optical Microscopy, Theory and Practice", 2 ${ }^{\text {nd }}$ ed. Al-Masirah House for Publishing, Distribution, and Printing, Amman, Jordan;.57p. 2010.

[22] F. Al-Qudsi and A. Al-Jahdali," Effect of monosodium glutamate on chick embryo development"IEEE Ameri. Scivol.8,no.10,pp. 499-509,2012.

[23] FA. Al-Ghamdi, 'The possible ameliorative effect of Grape Seed Extract against of Monosodium Glutamate (MSG) on retina of chick embryo during the incubation period (to Manifest Scientific Miracles in Quran)'IEEE Ameri.n Sci. vol.13,no.9,pp. 12-24,2017.

[24] MN. Ibrahim and SA. Hussian,"Histological Changes Indused by Monosodium Glutamate on the Growth and Development of the Offsprings Albino Mice Cornea",IEEE Tikrit .vol.7,no.22,pp. 49-59,2017.

[25] NM. Yenerel and RM. Kucumen,"Pregnancy and the eye"IEEE Turk. Ophthal. vol.45,no.5,pp. 213-219, (2015).

[26] R. A. Al-Najjar, The effect of involuntary smoking and alcohol on the embryogenesis and histopathology of the eye and causing abnormalities in the embryo of the Swiss white mouse Mus musculus. [master's thesis]. Iraq, University of Mosul, College of Education. Iraq;.36p. (2006). 